\title{
ANTECEDENTS OF WELL-BEING AT WORK: TRUST AND PEOPLE MANAGEMENT POLICIES
}

\author{
ÁUREA F. OLIVEIRA ${ }^{1}$ \\ (iD) https://orcid.org/0000-0001-5404-0540 \\ SINÉSIO GOMIDE JÚNIOR ${ }^{1}$ \\ (iD) https://orcid.org/0000-0003-0944-4380 \\ BÂNIA V. S. POLI ${ }^{2}$ \\ (iD) https://orcid.org/0000-0003-4364-5194
}

To cite this paper: Oliveira, A. F., Gomide Júnior, S., \& Poli, B. V. S. (2020). Antecedents of wellbeing at work: Trust and people management policies. Revista de Administração Mackenzie, 21 (1), 1-26. doi:10.1590/1678-6971/eRAMD200105

Submission: May 31, 2019. Acceptance: Sept. 11, 2019.

1 Universidade Federal de Uberlândia (UFU), Uberlândia, MG, Brazil.

2 Escola Superior de Administração, Marketing e Comunicação (Esamc), Uberlândia, MG, Brazil.

\section{(cc) BY




\section{ABSTRACT}

Purpose: The aim of this study was to investigate the impact of people management policies and organization trust on well-being at work, the latter being defined as the predominance of positive emotions at work and the individual's perception that, at work, he/she can express and develop his/her potential and, therefore, he/she progresses to achieving his life's goals.

Originality/value: The hypothesis underlying this research is that the work context presents itself as a privileged place for emotions and, fundamentally, for the realization and construction of personal happiness. The premise that the attainment of personal happiness is possible at work encourages people-management professionals to identify effective strategies for promoting well-being.

Design/methodology/approach: The sample consisted of 212 workers from various organizations who answered to instruments with evidence of validity and reliability. The model was tested by structural equation modeling and the reliability coefficients of the scales tested using Cronbach's alpha.

Findings: The results showed that the adjustment of the model is only reasonable, although, depending on the adjustment indices, it can be accepted. The results are discussed in terms of the contributions of the study to the expansion of knowledge in the area of organizational behavior and its implications for managerial actions. It is also suggested to carry out other studies covering larger samples and different natures.

\section{KEYWORDS}

People management policies. Organizational trust. Well-being at work. Happiness. Positive psychology. 


\section{INTRODUCTION}

Currently, people are important intangible assets for organizations, being considered their competitive edge. Administrating them has become the greatest challenge for managers that seek to create value, satisfaction and necessary conditions for the good performance of their employees, identifying effective strategies for promoting well-being in the workplace. Sinisammal, Belt, Härkönen, Möttönen, and Väyrynen (2012) affirmed that the benefits of well-being at work are extendable to employees, employers and the national economy. In the case of organizations, an appropriate level of well-being would increase quality and productivity, as well as positively influence the reduction of health problems that lead to sick leave.

From a positive standpoint, the bond formed between an individual and his/her employment organization is established through processes that promote employees' quality of life and pleasant, healthy experiences (Seligman \& Csikszentmihalyi, 2000). That being the case, well-being at the workplace, which is conceived as the "prevalence of positive emotions at work and the individual's perception that in his job he expresses and develops his potential/skills and advances toward achieving his goals in life" (Paschoal, 2008, p. 23), is an interesting and promising object of investigation, especially in terms of identifying variables capable of influencing this experience. It is within this context that the importance of human resource management practices and policies, and employees' trust in the organization that employs them emerges.

Based both on the literature that relates occupational well-being, perception of human resource management policies and organizational trust (Baptiste, 2008; Bos-Nehles \& Meijerink, 2018; Gomide, Silvestrin, \& Oliveira, 2015; Horta, Demo, \& Roure, 2012; Perilla-Toro \& Gómez-Ortiz, 2017; Tzafrir, 2005; White \& Bryson, 2013; Wood, Veldhoven, Croon, \& Menezes, 2012), and on new theoretical conceptions as to occupational well-being (Paschoal \& Tamayo, 2008) and trust (Ianaguivara, 2011), the present study seeks to enhance investigations related to the theme. Thus, we propose to identify the predictors of well-being at work, using perception of human resource management policies and organizational trust as antecedent variables. It is hoped that this study will contribute both to academic production in the area of human resource management (HRM) and to managers, helping them plan strategies for achieving their organizational objectives. 


\section{THEORETICAL FRAMEWORK}

\subsection{Well-being in the workplace}

The historical retrospective regarding the study of psychological wellbeing indicates that during the 1970s the economic aspect prevailed, relating this concept to salary income. Ryan and Deci (2001) organized their studies according to the hedonistic and eudaimonic approaches. The former refers to the subjective state of happiness, known as subjective well-being (SWB), while the latter focuses on human potential, or psychological well-being (PWB). SWB refers to people's self-assessments as to their lives, considering their emotional reactions and opinions regarding life satisfaction in various contexts, such as work and marriage. Psychological well-being refers to the functioning of a person's capabilities and encompasses the dimensions of self-acceptance, positive relations with others, autonomy, environmental mastery, life purpose and personal growth (Ryff \& Keyes, 1995; Ryff, 1989).

The historical perspective also reveals the contributions made by Danna and Griffin (1999) and DeJoy and Wilson (2003), when they refer to wellbeing in the workplace. According to these authors, the construct is part of individual well-being, which is expressed in terms of psychological and physical indicators that act in a synergistic manner, resulting in complex consequences for the individual.

According to Horn, Taris, Schaufeli, and Schreurs (2004), occupational well-being is a multidimensional concept associated with the positive assessment of emotional, motivational, behavioral and psychosomatic characteristics underlying the workplace context. For his part, Sirgy (2006) affirmed that well-being in the workplace is a state of satisfaction, happiness and subjective well-being that is intimately associated with job satisfaction. Conceiving occupational well-being as job satisfaction, Masagão and Ferreira (2015) identified a positive correlation between this variable and organizational justice. For their part, Schulte and Vainio (2010) characterized it as quality of life at work, going beyond the mere state of health, due to it reflecting the employee's satisfaction with his job and his life in general.

The concepts of well-being presented above indicate the existence of approaches that focus on life satisfaction, on the physical, mental and emotional aspects of the employee's health, and on his/her quality of life at work. In summary, the different approaches encompass conceptions of cognitive, affective, behavioral and physical aspects (Ferreira, Souza, \& Silva, 2012). 
The construct's conceptual diversity was explained by Paschoal et al. (2013, p. 385) when they affirmed, "there is consensus as to well-being's importance to the individual and the organization, but not as to the definition". These authors' standpoint is confirmed by the proposition of distinct conceptions of occupational well-being, as in Paschoal and Tamayo (2008), Dessen and Paz (2010), and Siqueira and Padovam (2008).

To Siqueira and Padovam (2008), well-being in the workplace is a multidimensional psychological construct consisting of positive affective ties with the work and the organization. An employee presumably would report a high level of well-being on the job when he feels satisfied with the work he performs, recognizes involvement with the tasks and maintains an affective commitment with his employing organization.

Dessen and Paz (2010), in relation to what concerns them, defined personal well-being in organizations as individuals' satisfaction of their needs and fulfillment of their desires in the performance of their organizational role. The cognitive and affective aspects contained in the definition would be evaluated via well-being indicators (appreciation of the work, personal recognition, autonomy, expectations of advancement, environmental support, financial resources, and pride) within the organizational scope. The authors also affirmed the existence of two extremities: gratification and discontentment. A person can feel gratified in relation to one aspect, yet discontented with another. An individual's well-being on the job is characterized when gratification exceeds discontentment.

As aforementioned, Paschoal and Tamayo (2008) defined well-being at work by way of the affective (positive affect, negative affect) and cognitive (personal achievement on the job) dimensions. The authors validated the Scale of Well-Being at Work (Escala de Percepção de Bem-Estar no Trabalho-EBET), employing the dimensions of emotions/moods and of perception of personal expressiveness and achievement in the workplace. The scale was validated in the United States, and the results maintained the structure identified in Brazil, as well as the indexes of reliability (Demo \& Paschoal, 2013). Considering the principles that formed the basis for the conception of well-being at work, which are founded upon hedonism and eudaimonism (two concepts that are also based on affective and cognitive dimensions), the present study will adopt this theoretical perspective. Furthermore, the EBET exhibits evidence of validity and reliability that makes its use appropriate.

Bearing in mind the conceptual divergence and the variety of available measures of well-being at the workplace, Paschoal (2008) reported difficulties 
in identifying the antecedents of this construct, suggesting situational variables associated with the occupational context and variables such as the employee's values, personality and preferences. Soraggi and Paschoal (2011) reaffirmed the presence of obstacles when they reported the use of the words happiness, well-being and quality of life as synonyms. In order to remedy this impasse, the scientific literature has adopted terms such as affect and well-being in the studies.

Among the international studies that have sought to understand the phenomenon of well-being at the workplace, Diez-Pinol, Dolan, Sierra, and Cannings (2008) examined the correlations between personal, organizational and cultural variables. The results showed that occupational well-being is not associated with personal factors, but with organizational factors related to the perception of culture and congruence between the organization's values. This affirmation is supported by the results of a study conducted in Brazil by Gomide et al. (2015), whose initial premise was that personal and organizational variables would be predictors of well-being at work. Nonetheless, the proposed model was not confirmed. Satisfaction with organizational supports was a consistent antecedent of well-being in corporate environments, but it was not dependent on resilience levels (personal variable). Also in regard to the role of individual factors and their relation to well-being on the job, Agapito, Polizzi, and Siqueira (2015) observed that turnover intention is affected by the level of well-being experienced by the employee, whereas perception of success in one's career exhibited less influence.

By way of interviews with researchers, consultants and managers who work for public and private organizations, a study conducted in Finland by Sinisammal et al. (2012) identified factors that influence occupational wellbeing. The content of the interviews resulted in five categories: employee (need for self-realization, equilibrium between work and private life, and health promotion), work (possibilities of self-development, significance of the work), group work (companionship, teamwork, positive attitudes in relation to diversity, mutual trust), management (clear practices and rules; communication and transparency; and managerial abilities), and external factors (macro-issues such as the local and global economy; laws; and microissues such as family, friends, personal relations and leisure time).

In Brazil, within the scope of public organizations, Baptiste (2008) investigated the relationship between leisure and well-being (composed of eight factors). Within the organizational context, the creation of conditions appropriate to leisure associates well-being with work-shift hours, stress 
management, communication strategies, pay strategies, management development, teamwork, stakeholder relations, and the clarification and reduction of initiatives for change.

Also in Brazil, one study indicates that the social atmosphere in organizations affects well-being in the workplace (Rocha \& Porto, 2012); perceptions of organizational and social support have a direct impact on occupational well-being (Paschoal, Torres, \& Porto, 2010). For their part, Couto and Paschoal (2012) studied the impact of employee-health-focused activities on well-being in the workplace, reporting that participation in activities aimed at employee health had a significant influence on negative affect. More recently, Sampaio, Gomide, and Oliveira (2019) examined the impact of perceptions as to human resource management policies and practices (HRMPP) - when mediated by perceptions of justice in organizations - on the occupational well-being reports of 83 psychologists, municipal public servants of a city in the Triângulo Mineiro region. The results indicated the prevalence of HRM policies and practices in the explanation of well-being, to the detriment of perceptions of organizational justice. There are, thus, indications that employee perception of a proposal made by the organization to create affective ties contribute to the well-being of its employees in terms of recognition, free communication and participation in decision making promotes positive reports of employee well-being.

Consistent with the tendency identified by Paschoal et al. (2013) in the literature, the present study's objective was to investigate the impact of human resource management policies and of organizational trust on wellbeing in the workplace, which is here defined as both the prevalence of positive emotions at work and the individual's perception that, in his/her work, he/she develops his/her potentials and makes progress in terms of achieving his/her goals in life.

\subsection{Human resources management policies}

HRM has undergone transformations in the last years due to the globalization of businesses, technological development and the intense movement for quality and productivity. Nonetheless, people differ in the way they behave, decide, work, and perform and improve their activities. This difference partly depends on organizations' policies and guidelines related to HRM (Ribeiro, 2005, p. 4). As such, HRM makes its conceptual and practical contribution when it seeks to promote a healthier life with legitimate results in terms of productivity, quality, development and sustainable competitiveness (França, 2008). 
To Coda, César, Bido, and Louffat (2009), strategic HRM proposals should encompass the analysis of factors such as organizational culture, alignment between organizational and human competencies, and employee commitment. It would be wise to add HRM policies to these factors, for they are capable of promoting greater employee well-being, thus fostering greater personal and professional achievement. Moreover, they contribute toward increased organizational effectiveness and competitiveness (Demo, 2010, 2016; Demo, Nunes, Ferreira, Melo, \& Oliveira, 2011).

The dimensions of HRM policies and practices identified by Demo in 2008 (involvement, training, development and education, working conditions, and compensation and compensation and rewards) resulted in the development and validation of the Scale of Perception of Human Resource Management Policies for assessing employees' perceptions in relation to the HRM policies implemented in organizations, which was subsequently expanded by Demo et al. (2011) to include policies related to recruitment and selection and the assessment of performance and skills. In 2012, the same instrument was validated in the United States, maintaining the 6-factor structure and satisfactory goodness-of-fit indexes (Demo \& Rozzet, 2012).

The conceptual approach and research instrument developed by Demo et al. (2011) are employed in the present study to examine the perception of human resource management policies variable in order to assess employees' perceptions as to organizational HRM policies.

\subsection{Trust in the organization}

Trust is a theme that has attracted the attention of researchers over the last three decades (Özyilmaz, 2010). Such interest has been manifested in various areas of study, such as political science, anthropology, sociology, psychology and economics. The study of trust can have various focal points, such as trust in supervisors, coworkers or organizations (Whitener, 1997). The present study focuses on employees' trust in the organization that employs them.

In the field of research on organizations, Fulmer and Gelfand (2012) affirmed that the study of trust has grown in recent years. This increase in the studies can be attributed to the benefits of trust for organizations and to the recognition of its importance in economic and social life. Kramer (1999) considered it a form of social capital in the organizational environment and associated its constructive effects (such as reduced transactional costs within organizations, increased spontaneous sociability between employees, and the facilitation of appropriate forms of deference) with organizational 
authorities. Trust in organizations appears to be an indispensable condition for the well-being of the employees, as well as providing a competitive edge.

The literature indicates that there is disagreement as to the definition of trust, as shown in Figure 2.3.1, which presents some of the concepts of this variable extracted from studies by Andersen (2005) and Hernandez and Santos (2010).

(Figure 2.3.1)

DEFINITIONS OF TRUST IN THE INTERNATIONAL LITERATURE

\begin{tabular}{ll}
\hline \multicolumn{1}{c}{ Author } & \multicolumn{1}{c}{ Definition } \\
\hline Rotter (1971) & $\begin{array}{l}\text { Trust is a generalized expectation on the part of any individual or group as } \\
\text { to the verbal or written word or promise of another individual or group. }\end{array}$ \\
\hline Sabel (1993) & $\begin{array}{l}\text { Mutual trust that no party to a relationship will exploit the vulnerability of } \\
\text { another party. }\end{array}$ \\
\hline $\begin{array}{l}\text { Mayer, Davis, and } \\
\text { Schoorman (1995) }\end{array}$ & $\begin{array}{l}\text { Trust is one party's willingness to be vulnerable to the actions of the other } \\
\text { party due to the expectation that the other will carry out an action of } \\
\text { particular importance to the "trusting party, regardless of the other's } \\
\text { capacity to monitor or control. }\end{array}$ \\
\hline Hosmer (1995) & $\begin{array}{l}\text { Trust is a person, group or company's expectation of ethically justifiable } \\
\text { behaviors by another person, group or company in a joint endeavor or } \\
\text { economic exchange. }\end{array}$ \\
\hline $\begin{array}{l}\text { Bhattacherjee } \\
\text { (2002) }\end{array}$ & $\begin{array}{l}\text { Trust is the expectation of positive or non-negative results that one can } \\
\text { receive based on the expected action of another party in an interaction } \\
\text { characterized by uncertainty; that is, trust is related to good results. }\end{array}$ \\
\hline $\begin{array}{l}\text { Rousseau, Sitkin, } \\
\text { Burt, and Camerer } \\
\text { (1998) }\end{array}$ & $\begin{array}{l}\text { A psychological state that involves the intention to accept vulnerability } \\
\text { basing oneself on positive expectations as to the intentions or behavior } \\
\text { of others. }\end{array}$ \\
\hline
\end{tabular}

Source: Adapted from Andersen (2005) and Hernandez and Santos (2010).

Analysis of the definitions presented above indicates two aspects: one with a positive connotation that is related to the expectation, reciprocity and trust that the other party will fulfill what is determined; and the other with a negative connotation, of vulnerability, that is, that trust is related to the perception of running risks. With respect to the latter, Kramer (1999) affirmed that trust involves a state of perception of risk and vulnerability, which derives from individual uncertainties as to the motives, intentions and actions of other people that the person depends on; it is, thus, a psychological state that includes affective and motivational components. 
According to Hernandez and Santos (2010), one of the commonly alleged reasons for the difficulty of conceptualizing trust is the fact that the theme has been the object of interest of various disciplines (psychology, sociology, political science, economics, anthropology and history), each of which addresses the concept according to its own perspective. Such diversity of approaches has led to variations in the definitions of the construct, thus reflecting the paradigms of each researcher's discipline of interest.

To Rousseau et al. (1998), trust can be studied as an independent variable (i.e., as something that produces cooperation and successful negotiations), as a dependent variable (i.e., as something that results from both management approaches and the trusted party's traits, such as competence and ability), and as a moderating variable, it being present in studies both on interpersonal behavior in organizations and on social relations. The present study focuses on the employee's trust in the organization as an independent variable capable of affecting the employee's experience of wellbeing at work. In order to assess it, we employed the Organizational Trust Inventory (Inventário de Confiança do Empregado na Organização - ICEO) (Ianaguivara, 2011), which consists of the following factors: ethical components, organizational competence, and opportunism. This construct is defined as
[...] a set of beliefs as to the ethical standards of the organization, the limited use of opportunism in its relations, and competence that is revealed in its technical capacity and financial solidity; therefore, the concept of employee trust in the organization is based on beliefs as to ethical standards, competence and limited opportunism (Ianaguivara, 2011, p. 79).

The present study seeks to increase knowledge regarding well-being in the occupational context and proposes an investigation of the impact of organizational variables on the hedonic (positive affect and negative affect) and eudaimonic (achievement) aspects of occupational well-being. The variables of interest to us are perception of HRM policies and employee trust in the organization (i.e., organizational trust), which consist of organizational and individual variables.

This hypothesis is supported by the notion that the workplace context is a unique emotional environment and, above all, an environment that involves the achievement and construction of personal happiness. The premise that the attainment of personal happiness in one's work is possible 
encourages HRM specialists to identify effective strategies for promoting well-being (Paschoal et al., 2010).

The proposed research model considers that perception of HRM policies and organizational trust are variables that explain occupational well-being. Accordingly, this study's objective is to test a hypothetical model in which well-being in the workplace is explained by perception of HRM policies and organizational trust.

\section{METHOD}

\subsection{Participants}

The convenience sample consisted of 212 formally employed workers, $71.9 \%$ of whom corresponded to the female gender, with ages ranging between 18 and 59 years, a mean age of $28(S D=8.66)$, and an average length of 3 years of employment $(S D=3.67)$. Their schooling levels ranged from an incomplete high-school education to postgraduate studies, however with the prevalence of an incomplete university education (35.5\%). Most of the participants worked for private organizations (82.4\%).

\subsection{Instruments}

The following instruments were employed for data collection:

- Scale of Well-being at Work (Paschoal \& Tamayo, 2008): consists of the factors "positive affects" (nine items; $\alpha=0.93$; example item - joyful), "negative affects" (12 items; $\alpha=0.91$; example item - frustrated), and "achievement/expressiveness" (nine items; $\alpha=0.88$; example item "I develop skills I consider important"). Items are rated according to a Likert scale ranging from 1 (I totally disagree) to 5 (I totally agree).

- Scale of Perception of Human Resource Management Policies (Demo et al., 2011): consists of the policies "recruitment and selection" (six items; $\alpha=0.84$; example item - "The selection tests of the organization I work for are conducted by trained, impartial people"), "involvement" (12 items; $\alpha=0.93$; example item - "The organization I work for encourages my participation in decision making and problem solving"), "training, development, and education" (six items; $\alpha=0.88$; example item - "The organization I work for invests in my development and education, 
greatly furthering my personal and professional growth"), "working conditions" (six items; $\alpha=0.84$; example item - "The facilities and physical conditions [lighting, ventilation, noise and temperature] of my workplace are ergonomic [adequate and comfortable]"), "evaluation of performance and skills" (five items; $\alpha=0.86$; example item - "In the organization I work for, evaluation of performance and skills aids decisions as to promotions and salary increases"), and "compensation and rewards" (five items; $\alpha=0.81$; example item - "In the organization I work for, my payment is influenced by my results"). Items are rated according to a Likert scale ranging from 1 (I totally disagree) to 5 (I totally agree).

- Organizational Trust Inventory (Ianaguivara, 2011): consists of three factors: "ethical components" (23 items; $\alpha=0.96$; example item - "This organization is well intentioned in regard to its employees"), "organizational competence" (14 items; $\alpha=0.92$; example item - "This organization keeps itself up to date in its line of work"), and "opportunism" (five items; $\alpha=0.84$; example item - "It is common for this organization to take advantage of its relationship with its employees"). Items are rated according to a Likert scale ranging from 1 (I totally disagree) to 5 (I totally agree).

\subsection{Data collection and analysis procedures}

In order to collect the data, we employed a notebook containing the general and specific instructions for filling out each of the three instruments, plus a sociodemographic info form. The employees that accepted participating in the study signed two copies of the informed consent form, one for the participant and one for the researchers' files.

Statistical analyses were performed via SPSS software (version 20). Exploratory analysis revealed less than $5 \%$ missing data, which was substituted by the mean of the data (Tabachnick \& Fidell, 2019).

We analyzed the symmetry and kurtosis indexes, and the results indicated a lack of normal distribution for various items. However, the asymmetry values were within acceptable limits, between 1.0 and 2.0, in accordance with Miles and Shevlin (2001).

For its part, multicollinearity did not affect the study's variables. The correlations between all the variables were within the parameters defined by Tabachnick and Fidell (2019), i.e., $r<0.90$.

Subsequently, we calculated Cronbach's alpha in order to check the consistency of the measures for the study's sample. Aiming at defining 
the best fit for the model, we employed the Analysis of Moment Structures (AMOS) statistical package, version 20.

\section{RESULTS}

The result as to the reliability of the scales for the study's sample was satisfactory, for it reached alpha values greater than 0.70 , which, according to Nunnally (1975), is the cutoff point for an accurate measure. The alpha values ranged from 0.76 (working conditions policies) to 0.96 (trust in ethical components), with a prevalence of values above .80 (Figure 4.1).

\section{(Figure 4.1)}

\section{RELIABILITY INDEXES FOR THE INSTRUMENTS' FACTORS}

\begin{tabular}{|c|c|c|c|}
\hline Instrument & Factor & No. of items & Cronbach's Alpha \\
\hline \multirow{6}{*}{$\begin{array}{l}\text { Scale of Perception of Human } \\
\text { Resource Management Policies } \\
\text { (Demo et al., 2011) }\end{array}$} & Recruitment and selection & 6 & 0.87 \\
\hline & Involvement & 12 & 0.91 \\
\hline & Working conditions & 6 & 0.76 \\
\hline & $\begin{array}{l}\text { Evaluation of performance } \\
\text { and skills }\end{array}$ & 5 & 0.90 \\
\hline & Compensation and rewards & 5 & 0.84 \\
\hline & $\begin{array}{l}\text { Training, development, and } \\
\text { education }\end{array}$ & 5 & 0.90 \\
\hline \multirow{3}{*}{$\begin{array}{l}\text { Organizational Trust Inventory } \\
\text { (lanaguivara, 2011) }\end{array}$} & Ethical components & 23 & 0.96 \\
\hline & Organizational competence & 14 & 0.90 \\
\hline & Opportunism & 5 & 0.81 \\
\hline \multirow{3}{*}{$\begin{array}{l}\text { Scale of Well-Being at Work } \\
\text { (Paschoal \& Tamayo, 2008) }\end{array}$} & Positive affect & 9 & 0.94 \\
\hline & Negative affect & 12 & 0.92 \\
\hline & Achievement & 9 & 0.90 \\
\hline
\end{tabular}

Source: Elaborated by the authors.

In order to check the model's suitability, we performed structural equation modeling, which consists of a modeling technique aimed at checking the validity of theories that propose hypothetical correlations between distinct models (Marôco, 2014). The global fit of the model was 
based on verification of the chi-squared $\left(\chi^{2}\right)$ values, goodness-of-fit index (GFI), comparative fit index (CFI), standardized root meansquare residual (SRMR) and root mean square error of approximation (RMSEA). The results are summarized in the Figure 4.2.

\section{(Figure 4.2)}

GOODNESS-OF-FIT INDEXES FOR THE MODEL

\begin{tabular}{lcl}
\hline Goodness-of-fit Index & Value obtained & \multicolumn{1}{c}{ Reference value } \\
\hline Chi-squared & $194.57^{\star \star}$ & The lower, the better $p>0.05$ \\
\hline GFI & $0.858^{*}$ & {$[0.8 ; 0.9]$ tolerable limit } \\
\hline CFI & $0.888^{\star}$ & $<0.8$ - poor fit \\
\hline RMSEA & $0.118^{\star}$ & $>0.10$ - unacceptable fit \\
\hline SRMR & $0.081^{\star}$ & \\
\hline
\end{tabular}

${ }^{*} p<0.05 ;{ }^{* *} p<0.01$

In light of the goodness-of-fit indexes obtained and the reference values proposed by Marôco (2014), the model is fragile, especially because we are dealing with confirmatory analysis. In general, the literature indicates that RMSEA values between .05 and .08 are acceptable (Fabrigar, Wegener, MacCallum, \& Strahan, 1999; Hu \& Bentler, 1999). To Kline (2005) and to $\mathrm{Hu}$ and Bentler (1999), SRMR values below 0.10 are satisfactory. The sample yielded a value equal to 0.081 , thus, meeting the criterion. On the other hand, the GFI and CFI values are less than 0.90, while only values greater than 0.90 are considered good (Kline, 2005; Carvalho \& Chima, 2014; Marôco, 2014). The improvement in the indexes described in Figure 4.2 occurred because of the correlation between the error terms of the policy factors involvement, evaluation of performance, and compensation and rewards (errors e5 and e2). The calculation of the adjusted model exhibited small differences in the group of fit indicators. Regardless, several indexes can be considered median.

The indexes indicate the model's limited fit to the sample data, suggesting that the model should be specified differently. Also, the correlation between the errors did not improve the model's fit substantially, which indicates that the model needs to be improved, including increasing the size of the sample in future studies. The diagram of the adjusted model is shown in Figure 4.3. 


\section{(Figure 4.3)}

ADJUSTED MODEL $(P \leq 0.001)$

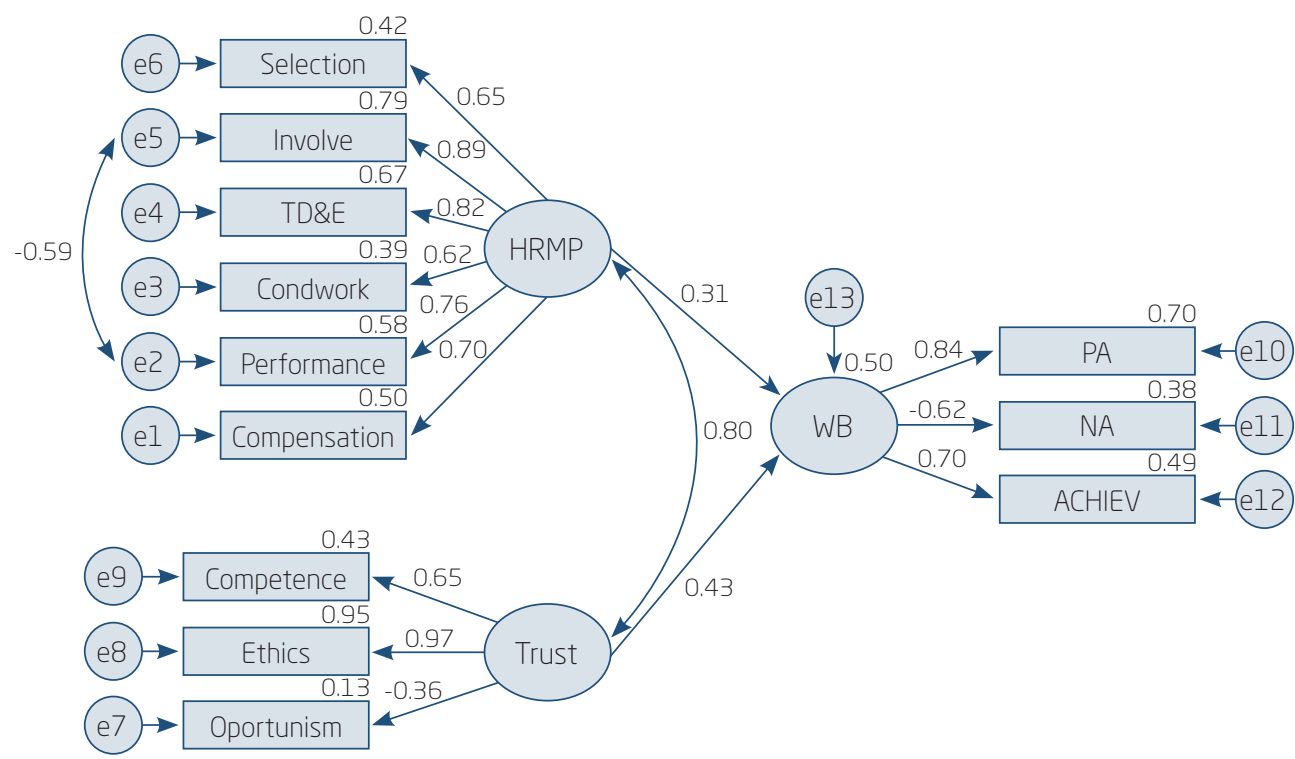

Selection = recruitment and selection; involve = involvement; TD\&E = training, development, and education; condwork = work conditions; performance = evaluation of performance and skills; compensation = compensation and rewards; competence = organizational competence; ethics = ethical components; HRMP = human resources management policies; $W B$ = well-being at work; $P A$ = posite affect; NA= negative affect; $A C H I E V=$ achievement.

Source: Elaborated by the authors.

In any case, the final result of the present study is consistent with national and international studies that found significant correlations between well-being in the workplace, perception of human resource management policies, and organizational trust (Baptiste, 2008; Horta et al., 2012; Innocentil, Pilati, \& Peluso, 2011). In addition, this study corroborates the information found in the literature that indicates the explanatory weight of the variables perception of involvement policies, trust in ethical standards and organizational competence in predicting occupational wellbeing.

\section{CONCLUSIONS}

This study's objective was to investigate the impact of HRM policies and organizational trust on well-being in the workplace, given that the 
workplace is where employees spend most of their time. The result of the test of the model achieved its objective by demonstrating correlations between the variables that make up the model.

Concrete involvement-policy initiatives include the following: identification of employees' skills and expectations; employee treatment based on respect and consideration; holding of events to integrate employees; recognition in the form of praise; articles in internal newsletters and positive feedback; encouragement of employee participation in decision making and problem solving; consideration of employees' ideas, suggestions and complaints (bottom-up communication); and dissemination of information relevant to job performance (Demo, 2008).

Accordingly, employees experience positive emotions at work (joy, motivation, disposition, contentment, happiness, excitement, enthusiasm, tranquility and pride), express their potentials and advance toward achieving their goals in life when they perceive that the organization cares about actively involving them in its operations and establishes a bond of trust based on ethical conduct and organizational competence. According to Richter and Näswall (2019), organizational trust is a typical characteristic of a healthy employer-employee relationship, it being related to the employee's well-being.

Discussing their conception of trust, Cummings and Bromiley (1996) refer to the individual belief - or common belief shared by a group of people - that another individual or group: 1. will make a good-faith effort to behave according to their explicitly or implicitly made commitment; 2 . will be honest in any negotiations that precede the commitment; and 3. will not take excessive advantage of others when the opportunity arises. This conception demonstrates the importance of ethical standards in the employee's experience of positive affects and occupational achievement. It also addresses belief in organizational competence, that is, belief in the organization's capacity to overcome crises, innovate and demonstrate its solidity and in its technical capacity and future perspective. On the other hand, opportunism that entails taking advantage of people, when possible, has the power to cause distrust. When this occurs, it facilitates experiences of negative affects (preoccupation, irritability, depression, boredom, annoyances, impatience, anxiety, nervousness, and tensions).

An organization's target should be the adoption of ethical principles, such as honesty, equality, benevolence, loyalty, transparency when the company disseminates information, the maintenance of commitments, and respect. HRM policies and practices that reveal the organization's integrity 
and benevolence, in order to avoid job insecurity, are also important. Hence, the organization's trustworthiness, when perceived by the employees, can promote their well-being at work (Richter \& Näswall, 2019).

Richter and Näswall (2019) associate loss of trust with employers' unforeseeable future behaviors and with a low level of well-being at the workplace. There is an underlying mechanism that indicates a breach of the psychological contract and a lack of reciprocity. As such, trust can be viewed as a mechanism that maintains social relations in general, as well as at the workplace.

Positive psychology focuses on individuals' healthy aspects, favoring the comprehension of the mechanisms that lead to healthiness, to the detriment of illness (Seligman \& Csikszentmihalyi, 2000). Within this context, the present research is based on such a perspective, for it centers on practices and policies that create opportunities for employees' growth and involvement in the work environment. Consequently, practices and policies that adopt this perspective produce perceptions, and thus, reports of positive experiences and happiness, that is, of well-being at work. The present study makes an important contribution to the area of organizational behavior, for it investigated a previously little-explored relationship between constructs. One study by Horta et al. (2012) examined Siqueira and Padovam's (2008) concept of occupational well-being consisting of employees' positive emotional ties with their jobs (satisfaction and involvement) and with their organizations (affective organizational commitment). For this reason, other studies of this variable appear to be necessary in order to test this model in other contexts, aiming at increasing knowledge about human resource management policies, trust and occupational well-being and their interactions with other variables (Horta et al., 2012). Such studies could encompass the theoretical concept of well-being proposed by Paschoal and Tamayo (2008), which contains hedonic and eudaimonic elements portrayed via affects and cognitions.

Currently, with respect to the need to retain talent in an environment characterized by competition, pressure to meet goals, and the difficulty of maintaining the employment relationship, there is a great probability that negative affects (preoccupation, irritability, depression, boredom, annoyances, impatience, anxiety and others) will prevail.

On one side of the relationship, there is the employee, who seeks to be appreciated, recognized and happy in the workplace; and on the other side, the organization, which seeks professionals that are more committed and more competent. It is a relationship of social exchange based on trust 
and good faith between the parties to the relationship: employee and employer. Management practices (especially those related to involvement), if effectively implemented and perceived by the employees, would be fundamental elements in the experience of well-being at work.

We, thus, believe that the present study's observations and contributions can be utilized by the organizations in the HRM and in the implementing of involvement policies. When perceived by employees to be just and coherent for the entire workforce, such policies can foster the presence of employees with a high level of well-being, which, in turn, can result in reduced employee turnover and greater productivity.

The results of this study will encourage managers to include, in their strategic planning, mechanisms for promoting occupational well-being by way of making changes to HRM practices and policies. In the contemporary HRM model, one observes that HRM policies acquire a special connotation in relation to the development, appreciation and retention of talent. The employee's essential role in the process of achieving goals and making decisions is taken as a point of reference, aiming at greater organizational efficiency and competitiveness (Demo, 2010). HRM practices and policies and employees' trust in the organization are useful instruments in human resource management.

One of the limitations of the present study is the fact that it is a crosssectional study. Furthermore, its results cannot be generalized, because it involves a convenience sample specific to a single region in Brazil. Given that structural equation modeling is sensitive to sample size, we suggest employing larger samples in future studies, although 200 cases are considered acceptable. In addition, it would be necessary to test the proposed model on other samples. By employing such procedures, it would be possible to check whether the fit indexes would remain the same or be improved.

With respect to future studies aimed at increasing knowledge about variables that are capable of influencing well-being at the workplace, we recommend conducting longitudinal studies. We also suggest including characteristics such as different organizational sizes and lines of business, for such characteristics could affect perception of expressiveness and personal achievement at work. Such a possibility is based on the premise that such organizations possess particularities in relation to HRM policies and trust-producing mechanisms. Accordingly, it is necessary to conduct studies within specific contexts and assess aspects that could affect employees' experiences of well-being in the workplace. 


\section{ANTECEDENTES DE BEM-ESTAR NO TRABALHO: CONFIANÇA E POLÍTICAS DE GESTÃO DE PESSOAS}

\section{) RESUMO}

Objetivo: Este estudo teve por objetivo investigar o impacto de políticas de gestão de pessoas e da confiança organizacional sobre o bem-estar no trabalho, definido aqui como a prevalência de emoções positivas no trabalho acrescida da percepção do indivíduo de que, no seu trabalho, desenvolve seus potenciais e avança no alcance de suas metas de vida.

Originalidade/valor: A hipótese que sustenta esta investigação é de que o contexto de trabalho se apresenta como lugar privilegiado de emoções e, fundamentalmente, de realização e de construção da felicidade pessoal. A premissa de que o alcance da felicidade pessoal é possível no trabalho incentiva os profissionais de gestão de pessoas a identificar estratégias eficazes na promoção do bem-estar.

Design/metodologia/abordagem: A amostra foi composta por 212 trabalhadores de diversas organizações que responderam a instrumentos com evidência de validade e fidedignidade. O modelo foi testado pela Modelagem de Equações Estruturais e os coeficientes de fidedignidade das escalas testados por meio do alfa de Cronbach.

Resultados: Os resultados apontaram que o ajustamento do modelo é apenas razoável, embora, em função dos índices de ajustamento, possa ser aceito. Os resultados são discutidos em termos das contribuições do estudo para a ampliação do conhecimento na área do comportamento organizacional e em suas implicações para ações gerenciais. Sugere-se, ainda, a realização de outros estudos abrangendo amostras mais amplas e de diferentes naturezas.

\section{PALAVRAS-CHAVE}

Políticas de gestão de pessoas. Confiança organizacional. Bem-estar no trabalho. Felicidade. Psicologia positiva. 


\section{REFERENCES}

Agapito, P. R., Polizzi, A., Filho, \& Siqueira, M. M. M. (2015). Bem-estar no trabalho e percepção de sucesso na carreira como antecedentes de intenção de rotatividade. Revista Administração Mackenzie, 16(6), 71-93. doi:10.15 90/1678-69712015/administracao.v16n6p71-93

Andersen, J. A. (2005). Trust in managers: A study of why Swedish subordinates trust their managers. Business Ethics: A European Review, 14(4), 392-404. doi:10.1111/j.1467-8608.2005.00420.x

Baptiste, N. R. (2008). Tightening the link between employee wellbeing at work and performance: A new dimension for HRM. Management Decision, 46(2), 284-309. doi:10.1108/00251740810854168

Bhattacherjee, A. (2002). Individual trust in online firms: Scale development and initial test. Journal of Management Systems, 19(1), 211-241.

Bos-Nehles, A. C., \& Meijerink, J. G. (2018). HRM implementation by multiple HRM actors: A social exchange perspective. The International Journal of Human Resource Management, 29 (22), 3068-3092. doi:10.1080/09 585192.2018.1443958

Carvalho, J. D., \& Chima, F. O. (2014). Applications of structural equation modeling in social sciences research. American International Journal of Contemporary Research, 4(1), 6-11. Retrieved from http://www.aijcrnet. com/journals/Vol_4_No_1_January_2014/2.pdf

Coda, R., César, A. M. R. V. C., Bido, D. S., \& Louffat, E. (2009). Strategic HR? A study of the perceived role of HRM departments in Brazil and Peru. Brazilian Administration Review, 6(1), 15-33. doi:10.1590/S1807-76922009 000100003

Couto, P. R., \& Paschoal, T. (2012). Relação entre ações de qualidade de vida no trabalho e bem-estar laboral. Psicologia Argumento, 30(70), 585-593. doi:10.7213/psicol.argum.6145

Cummings, L. L., \& Bromiley, P. (1996). The organizational trust inventory. In R. M. Kramer \& T. R. Tyler (Eds.). Trust in organizations: Frontiers of theory and research (pp. 302-330). Thousand Oaks: Sage.

Danna, K., \& Griffin, R. W. (1999). Healthy and wellbeing in the workplace: A review and synthesis of the literature. Journal of Management, 25(3), 357-384. doi:10.1177/014920639902500305

DeJoy, D. M., \& Wilson, M. G. (2003). Organizational health promotion: Broadening the horizon of workplace health promotion. American Journal of Health Promotion, 17(5), 337-341. doi:10.4278/0890-1171-17.5.337 
Demo, G. (2008). Desenvolvimento e validação da Escala de Percepção de Políticas de Gestão de Pessoas (EPPGP). Revista de Administração Mackenzie, 9(6), 77-101. doi:10.1590/S1678-69712008000600005

Demo, G. (2010). Políticas de gestão de pessoas, valores pessoais e justiça organizacional. Revista de Administração Mackenzie, 11 (5), 55-81. doi:10.15 90/S1678-69712010000500004

Demo, G. (2016). Políticas e práticas de gestão de pessoas: Possibilidades de diagnóstico para gestão organizacional. In H. Mendonça, M. C. Ferreira, \& E. R. Neiva (Orgs.). Análise e diagnóstico organizacional: Teoria e prática (pp. 117-148). São Paulo: Vetor.

Demo, G., Nunes, I., Ferreira, L. A., Melo, B. B., \& Oliveira, K. R. (2011, outubro). Escala de Percepção de Políticas de Gestão de Pessoas (EPPGP): Validação fatorial exploratória. Anais do Encontro Nacional de Engenharia de Produção, Belo Horizonte, MG, Brasil, 31.

Demo, G., \& Paschoal, T. (2013, setembro). Well being at work scale: Exploratory and confirmatory validation in the United States comprising affective and cognitive components. Anais do Encontro Nacional de Pós-Graduação e Pesquisa em Administração, Rio de Janeiro, RJ, Brasil, 37.

Demo, G., \& Rozzet, K. (2012). Human resource management policies and practices (HRMPP): Scale validation in the Unites States. International Journal of Strategic Management, 12(3), 41-66.

Dessen, C., \& Paz, M. G. T. (2010). Bem-estar pessoal nas organizações: O impacto das configurações de poder e características de personalidade. Psicologia: Teoria e Pesquisa, 26(3), 549-556. doi:10.1590/S0102-3772201 0000300018

Diez-Pinol, M., Dolan, S. L., Sierra, V., \& Cannings, K. (2008). Personal and organizational determinants of well-being at work: The case of Swedish physicians. International Journal of Health Care Quality Assurance, 21(6), 598-610. doi:10.1108/09526860810900754

Fabrigar, L. R., Wegener, D. T., MacCallum, R. C., \& Strahan, E. J. (1999). Evaluating the use of exploratory factor analysis in psychological research. Psychological Methods, 4(3), 272-299. doi:10.1037/1082-989X.4.3.272.

Ferreira, M. C., Souza, M. A., \& Silva, C. A. (2012). Qualidade de vida e bem-estar no trabalho: Principais tendências e perspectivas teóricas. In M. C. Ferreira \& H. Mendonça (Orgs.). Saúde e bem-estar no trabalho: Dimensões individuais e culturais (pp. 79-104). São Paulo: Casa do Psicólogo.

França, A. C. L. (2008). Práticas de recursos humanos - PRH: Conceitos, ferramentas e procedimentos. São Paulo: Atlas. 
Fulmer, C. A., \& Gelfand, M. J. (2012). At what level (and in whom) we trust. Journal of Management, 38(4), 1167-1230. doi:10.1177/01492063 12439327

Gomide, S., Junior, Silvestrin, L. H. B., \& Oliveira, A. F. (2015). Bem-estar no trabalho: O impacto das satisfações com os suportes organizacionais e o papel mediador da resiliência no trabalho. Revista Psicologia: Organizações e Trabalho, 15(1), 19-29. doi:10.17652/rpot/2015.1.349

Hernandez, J. M. C., \& Santos, C. C. (2010). Development-based trust: Proposing and validating a new trust measurement model for buyer-seller relationships. Brazilian Administration Review, 7(2), 172-197. doi:10.1590/ S1807-76922010000200005

Horn, J. E. van, Taris, T. W., Schaufeli, W. B., \& Schreurs, P. J. G. (2004). The structure of occupational well-being: A study among Dutch teachers. Journal of Occupational and Organizational Psychology, 77(3), 365-375. doi:10.1348/0963179041752718

Horta, P., Demo, G., \& Roure, P. (2012). Políticas de gestão de pessoas, confiança e bem-estar no trabalho: Estudo em uma multinacional. Revista de Administração Contemporânea, 16(4), 566-585. doi:10.1590/S1415-655520 12000400005

Hosmer, L. T. (1995). Trust: The connecting link between organizational theory and philosophical ethics. Academy of Management Review, 20(2), 379-403. doi:10.2307/258851

Hu, L.-T., \& Bentler, P. M. (1999). Cut off criteria for fit indexes in covariance structure analysis: Convention al criteria versus new alternatives. Structural Equation Modeling, 6(1), 1-55. doi:10.1080/10705519909540118

Ianaguivara, C. M. G. A. (2011). Confiança do empregado na organização: Construção e validação de instrumento de medida (Dissertação de mestrado, Universidade Federal de Uberlândia, Uberlândia, MG, Brasil).

Innocentil, L., Pilati, M., \& Peluso, A. M. (2011). Trust as moderator in the relationship between HRM practices and employee attitudes. Human Resource Management Journal, 21 (3), 303-317. doi:10.1111/j.1748-8583. 2010.00151.x

Kramer, R. M. (1999).Trust and distrust in organizations: Emerging perspectives, enduring questions. Annual Review Psychology, 50(1), 569-598. doi:10.1146/annurev.psych.50.1.569

Kline, R. B. (2005). Methodology in the social sciences. Principles and practice of structural equation modeling (2nd ed.). New York: Guilford Press. 
Masagão, V. C., \& Ferreira, M. C. (2015). O impacto da justiça organizacional sobre o bem-estar laboral: Um estudo com trabalhadores do varejo. Revista Psicologia: Organizações e Trabalho, 15(1), 8-18. doi:10.17652/rpot/ 2015.1.327

Marôco, J. (2014). Análise de equações estruturais: Fundamentos teóricos, software $\mathcal{E}$ aplicações (2a ed.). Pêro Pinheiro, Portugal: Cafilesa.

Mayer, R. C., Davis, J. H., \& Schoorman, F. D. (1995). An integrative model of organizational trust. Academy of Management Review, 20(3), 709-734. doi: $10.2307 / 258792$

Miles, J. N. V., \& Shevlin, M. E. (2001). Applying regression and correlation: A guide for students and researchers. London: Sage.

Nunnally, J. C. (1975). Psychometric theory - 25 years ago and now. Educational Research, 4(10), 7-21. doi:10.3102/0013189X004010007

Özyilmaz, Y. D. A. (2010). Vertical trust in organizations: A review of empirical studies over the last decade. Journal of Social Sciences Institute, 7(13), 1-28.

Paschoal, T. (2008). Bem-estar no trabalho: Relações com suporte organizacional, prioridades axiológicas e oportunidades de alcance de valores pessoais no trabalho (Tese de doutorado, Universidade de Brasília, Brasília, DF, Brasil).

Paschoal, T., Demo, G., Fogaça, N., Ponte, V., Edrei, L., Francischeto, L., \& Albuquerque, G. (2013). Bem-estar no trabalho: Cenário dos estudos brasileiros publicados na primeira década do novo milênio. Human Resources, Business Ethics \& Governance, 2 (ed. esp.), 383-395.

Paschoal, T., \& Tamayo, A. (2008). Construção e validação da escala de bem-estar no trabalho. Avaliação Psicológica, 7(1), 11-22. doi:10.1590/S141565552012000200006

Paschoal, T., Torres, C. V., \& Porto, J. B. (2010). Felicidade no trabalho: Relações com suporte organizacional e suporte social. Revista de Administração Contemporânea, 14(6), 1054-1072. doi:10.1590/S1415-655520100007 00005

Perilla-Toro, L. E., \& Gómez-Ortiz, V. (2017). Relación del estilo de liderazgo transformacional con la salud y elbienestar del empleado: El rol mediador de la confianza en el líder. Journal of Work and Organizational Psychology, 33, 95-108. doi:10.1016/j.rpto.2017.02.005

Ribeiro, A. L. (2005). Gestão de pessoas. São Paulo: Saraiva.

Richter, A., \& Näswall, K. (2019). Job insecurity and trust: Uncovering a mechanism linking job insecurity to well-being. Work \& Stress, 33(1), 22-40. doi:10.1080/02678373.2018.1461709 
Rocha, F., Sobrinho, \& Porto, J. B. (2012). Bem-estar no trabalho: Um estudo sobre suas relações com clima social, coping e variáveis demográficas. Revista de Administração Contemporânea, 16(2), 253-270. doi:10.1590/ S1415-65552012000200006

Rotter, J. B. (1971). Generalized expectancies for interpersonal trust. American Psychologist, 26(5), 443-452. doi:10.1037/h0031464

Rousseau, D., Sitkin, S., Burt, R., \& Camerer, C. (1998). Not so different after all: A cross-discipline view of trust. Academy of Management Review, 23(3), 393-404. doi:10.5465/AMR.1998.926617

Ryan, R. M., \& Deci, E. L. (2001). On happiness and human potentials: A review of research on hedonic and eudaimonic well-being. Annual Review Psychology, 52(1), 141-166. doi:10.1146/annurev.psych.52.1.141

Ryff, C. D. (1989). Happiness is everything, or is it? Explorations on the meaning of psychological well-being. Journal of Personality and Social Psychology, 57(6), 1069-1081. doi:10.1037/0022-3514.57.6.1069

Ryff, C. D., \& Keyes, C. L. M. (1995). The structure of psychological wellbeing revisited. Journal of Personality and Social Psychology, 69(4), 719-727. doi:10.1037/0022-3514.69.4.719

Sabel, C. F. (1993). Studied trust: Building new forms of cooperation in a volatile economy. Human Relations, 46(9) 1133-1170. doi:10.1177/00187 2679304600907

Sampaio, T. A., Gomide, S., \& Oliveira, A. F. (2019). Bem-estar no trabalho, gestão e justiça no trabalho em modelo mediacional. Revista Laborativa, 8(1), 26-43. Retrieved from http://ojs.unesp.br/indexphp/rlaborativa

Schulte, P., \& Vainio, H. (2010). Well-being at work - overview and perspective. Scandinavian Journal of Work, Environment \& Health, 36 (5), 422-429. doi:10.2307/40967878

Seligman, M. E. P., \& Csikszentmihalyi, M. (2000). Positive psychology: An introduction. American Psychologist, 55(1), 5-14. doi:10.1037/0003-066X. 55.1 .5

Sinisammal, J., Belt, P., Härkönen, J., Möttönen, M., \& Väyrynen, S. (2012). Managing well-being at work during 2010s - Expert viewpoints. Open Journal of Safety Science and Technology, 2(1), 25-31. doi:10.4236/ojsst. 2012.21004

Siqueira, M. M. M., \& Padovam, V. A. R. (2008). Bases teóricas de bem-estar subjetivo, bem-estar psicológico e bem-estar no trabalho. Psicologia: Teoria e Pesquisa, 24(2), 201-209. 
Sirgy, M. J. (2006). Developing a conceptual framework of Employee Wellbeing (EWB) by applying goal concepts and findings from personalitysocial psychology. Applied Research in Quality of Life, 1(1), 7-38. doi:10.10 07/s11482-006-9000-4

Soraggi, F., \& Paschoal, T. (2011). Relação entre bem-estar no trabalho, valores pessoais e oportunidades de alcance de valores pessoais no trabalho. Estudos e Pesquisas em Psicologia, 11 (2), 614-632. Retrieved from http:// pepsic.bvsalud.org/scielo.php?script $=$ sci_arttext\&pid $=$ S1808-42812011 000200016\&lng $=\mathrm{pt \& t} \operatorname{lng}=\mathrm{pt}$

Tabachnick, B. G., \& Fidell, L. S. (2019). Using multivariate statistics (7. ed.). Boston: Pearson.

Tzafrir, S. S. (2005). The relationship between trust, HRM practices and firm performance. International Journal of Human Resource Management, 16(9), 1600-1622. doi:10.1080/09585190500239135

White, M., \& Bryson, A. (2013). Positive employee attitudes: How much human resource management do you need? Human Relations, 66(3), 385-406. doi:10.1177/0018726712465096

Whitener, E. M. (1997). The impact of human resource activities on employee trust. Human Resource Management Review, 7(4), 384-404. doi:10.1016/S10 53-4822(97) 90026-7

Wood, S., Veldhoven, M. van, Croon, M., \& Menezes, L. M. (2012). Enriched job design, high involvement management and organizational performance: The mediating roles of job satisfaction and well-being. Human Relations, 65(4), 419-445. doi:10.1177/0018726711432476

\section{AUTHOR NOTES}

Áurea F. Oliveira, Ph.D. by the Institute of Psychology, Brasília University (UnB); Sinésio Gomide Júnior, Ph.D. by the Institute of Psychology, Brasília University (UnB); Bânia V. S. Poli, master by the Institute of Psychology, Federal University of Uberlândia (UFU).

Áurea F. Oliveira is now associate professor at the Institute of Psychology of Federal University of Uberlândia (UFU); Sinésio Gomide Júnior is now professor at the Institute of Psychology of Federal University of Uberlândia (UFU); Bânia V. S. Poli is now professor at the Business Department of School of Administration, Marketing and Communication (Esamc).

Correspondence concerning this article should be addressed to Áurea F. Oliveira, Avenida Pará, 1720, Bloco 2C, Umuarama, Uberlândia, Minas Gerais, Brazil, CEP 38405-240.

E-mail: aurea.oliveira@ufu.br 


\section{Áurea F. Oliveira, Sinésio Gomide Júnior, Bânia V. S. Poli}

\section{EDITORIAL BOARD}

Editors-in-chief

Janette Brunstein

Silvia Marcia Russi de Domênico

Associated Editor

Mary Sandra Carlotto

Technical Support

Vitória Batista Santos Silva

\section{EDITORIAL PRODUCTION}

Publishing Coordination

Jéssica Dametta

Layout Designer

Emap

Editorial Intern

Paula Di Sessa Vavlis

Graphic Designer

Libro

\section{Language Editor}

Daniel de Almeida Leão 